\title{
アフィニティークロマトグラフィーと白金コロイド染色法を 組み合わせたタンパク質の特異的高感度定量法
}

\author{
(1990 年 8 月 27 日受理)
}

蓮実文彦*半田晴久・大倉一郎**

放射性同位体を用いることなくタンパク質を特異的で高感度に定量する方法の開発を行った。この方 法は, 抗体を配位子としたアフィニティークロマトグラフィーによりタンパク質を特異的に分離し, 得 られたタンパク質溶液について白金コロイドを用いたタンパク質染色法により定量するものである。本 研究では, ヒト血清中からのヒトアルブミン拉よびヒトインスリンの分離定量を試みた。ヒトアルブミ ンでは $1 \mathrm{ng}$ の検出感度を有し, ヒトインスリンでは 1 ～20 ng で検出, 定量が可能であることがわか った。

\section{1 緒言}

臨床検查においては, 生体内に微量しか存在しない特定の酵素 やホルモンを末梢血蜲などから，選択的に定量しなければならな い場合がある。その際用いられる方法としては，放射免疫検定 $(\mathrm{RIA})^{122)}$ や酔素免疫測定法 (ELISA) ${ }^{314)}$ などが知られている。 しかしながら，RIAを実施するには，放射性同位体を用いるため 特別な施設を必要とする。また，ELISA 法は簡便であるが，検出 感度が ng 程度であり，十分な検出感度とはいえない。

そこで本研究では,すでに報告したタンパク質の高感度検出法 (白金コロイド染色法 $)^{5)}$ に, アフィニティークロマトグラフィー を組み合わせ, 特異的で高感度なタンパク質の定量法の開発を試 みた。前報では, 白金コロイド染色法を用いると卵白アルブミン が高感度 $(0.1 \mathrm{pg} / 10 \mu l$ 程度) で険出できることを報告した。し かし, 本法の染色機構が, タンパク質と白金コロイド粒子の静電 的相互作用に基づいているため，特異性に欠けていた。そこで， この方法に特異性を付与するため, アフィニティークロマトグラ フィーを組み合わせることを試みた。すなわち, 複数のタンパク 質が混在する溶液から, 目的のタンパク質のみを分離し, 得られ たタンパク質溶液について白金コロイド染色法によりタンパク質 の定量を行ら方法である。ここではヒトアルブミン (HSA) とヒ

沼津工業高等専門学校工業化学科, 410 沼津市大阔

** 東京工業大学生命理工学部生物工学科, 152 東京都目黒 区大岡山

1) S. A.Berson, R.S. Yallow, J. Clin. Invest., 38, 1966 (1959).

2) "Methods in Investigative and Diagnostic Endocrinology", ed. by S. A. Berson, R. S. Yallow, North Holland Publishing Co., Amsterdam, 2 A (1973).

3) S. Hsu, L. Raine, H. Fanger, J. Histochem. Cytochem., 29, 577(1981).

4) E. Ishikawa, M. Imagawa, S. Hashida, S. Yoshitake, Y. Hamaguchi, T. Ueno, J. Immunoassay, 4, 209 (1983).

5）蓮実文彦，高野正男，大倉一郎，日化，1989，1169.
トインスリンの 2 種類のタンパク質を試料として検討を行った。

\section{2 実験}

\section{1 試 薬}

HSA およびヒトインスリンは, 大塚製薬(株)製および SIGMA 社製のものを使用した。ヒト血清は, 健康成人から採血し遠心分 離したものを用いた。アフィニティークロマトグラフィーの配位 子としては, 抗ヒトアルブミンと抗ヒトインスリンの 2 種類のポ リクローナル抗体を用いた。このらち抗ヒトアルブミン抗体は, Calzyme Laboratories 社製のウサギ由来のものをそのまま使用 した。抗ヒトインスリン抗体は, 東洋醸造(株)により次の方法で 調製し提供されたものを使用した。ヒトインスリンを免疫したマ ウス血清を塩析，イオンクロマトグラフィー，ゲル沪過の各精製 操作後に得られた IgG 画分を抗ヒトインスリン抗体とした。こ の溶液の IgG 濃度は, $280 \mathrm{~nm}$ の吸光度測定から約 $1 \mathrm{mg} / \mathrm{ml}$ で あった。他の試薬はすべて市販特級品をそのまま使用した。

\section{2 アフィニティークロマトグラフィーの調製}

アフィニティークロマトグラフィーには, 抗ヒトアルブミン抗 体 (Calzyme Laboratories 社製) および抗ヒトインスリン抗体 （東洋醸造(株)より提供）を配位子とし, $\mathrm{CNBr}$-活性化セファ口 ースカップリングゲル（ファルマシア社製）担体に固定化したも のを用いた。CNBr-活性化七ファロースへの抗ヒトアルブミン抗 体扰よび抗ヒトインスリン抗体のカップリングは文献6) に基づい て行った。CNBr-活性化セファロースは $1 \mathrm{~g}$ ，抗ヒトアルブミン 抗体は $1 \mathrm{ml}$ ，また抗ヒトインスリン抗体は $0.5 \mathrm{ml}$ をそれぞれ用 い調製した。カップリングゲルは, 内容積約 $10 \mathrm{ml}$ のカラムに充 填し, $50 \mathrm{mmol} / l$ リン酸塩緩衝液 $(\mathrm{pH} 7.0), 100 \mathrm{mmol} / l$ 酢酸塩緩 衝液（pH 4.0）抽よ゙ $100 \mathrm{mmol} / l$ 炭酸塩緩衝液（pH 8.0）のそ れぞれ $50 \mathrm{~m} l$ で交互に洗浄し，白金コロイド染色法で各洗液中に タンパク質が検出されなくなるまでくり返し洗浄した後実験に用 いた。

6) H. G. van Eijk, W. L. van Noort, J. Clin. Chem. Biochem., 14, 475(1976). 
ヒト血清中の HSA の分離操作は以下のようにして行った。抗 ヒトアルブミン抗体をカップリングしたゲル $3.5 \mathrm{ml}$ をカラムに 充填し, ヒト血清を $10^{5}$ 倍に希釈した溶液 $3.5 \mathrm{ml}$ を導入後, 室 温で 30 分間放置した。その後ゲルを $\mathrm{pH} 7.0$ のリン酸塩緩衝液 $50 \mathrm{ml}$ で洗浄し，白金コロイド染色法で洗液中にタンパク質が検 出されないことを確認した。次にカラムゲル内を $\mathrm{pH} 4.0$ の酢酸 塩緩衝液 $3.5 \mathrm{~m} l$ で置換し, 室温で 30 分間放置することにより吸 着した HSA の溶出を行った。得られた溶出液を採取し, このう ち $10 \mu l$ をセルロースアセテート膜 (CE 膜) 上に滴下し, 乾燥固 定後, 白金コロイド染色を行った。また, この方法で使用したカ ラムゲルは, 10 回前後の吸着脱離を行っても良好な再現が得ら れた。

\section{3 白金コロイド染色法}

2.3.1 白金コロイドの調製：白金コロイドは, Turkevich ら の方法 ${ }^{7) ~ 9)}$ に基ついて調製した。すなわち, $1.0 \times 10^{-4} \mathrm{~mol} / l$ 塩化 白金酸水溶液 $1 l$ を加熱沸騰後 $3.4 \times 10^{-2} \mathrm{~mol} / l$ クエン酸ナトリ ウム水溶液 $0.12 l$ を加光 4 時間環流することにより白金コロイ ドの調製を行った。

2.3.2 銅めっき染色：アフィニティークロマトグラフィーに より分離されたタンパク質溶液は, $\mathrm{CE}$ 膜上に $10 \mu l$ 滴下し乾燥 固定した。この CE 膜を白金コロイド溶液に 5 分間浸漬した。そ の後蒸留水に 4 分間浸漬放置することにより物理吸着分の白金コ ロイドを除去した。つぎに銅めっき液（酒石酸カリウムナトリウ ム $170 \mathrm{~g}$, 硫酸銅 $(\mathrm{II})$ 五水和物 $47 \mathrm{~g}$, 炭酸ナトリウム $30 \mathrm{~g}$, EDTA $2 \mathrm{Na} 20 \mathrm{~g}$, 水酸化ナトリウム $30 \mathrm{~g}$ を加えて水 $1 l$ とした もの） 5 容に対し $37 \%$ ホルマリン 1 容の割合で調製しためっき 浴に, 水洗後の $\mathrm{CE}$ 膜を室温で約 5 分間浸漬し, その後ただちに 水洗した。

\section{4 染色濃度測定}

白金コロイド銅めっき染色により得られた染色像をビデオカメ ラとマイクロコンピュータから成る画像処理装置 (東洋醸造(株) 製 TIF-64）を用いて染色濃度测定を行った。

\section{5 二次元電気泳動法によるヒトアルブミンの純度検定}

アフィニティークロマトグラフィーにより得られた溶出液 50 $\mathrm{m} l$ を回収し, 蒸発器を用いて濃縮した（約 300 倍に濃縮）。この 濃縮液を試料とし, 東洋醇造(株)製ミクロ多検体二次元電気泳動 装置 $(\mathrm{OMS}-\mathrm{B})$ を用い等電点電気泳動を一次元目に, グラジェン トゲルによるアクリルアミドゲル電気泳動を二次元目とする二次 元電気泳動法を行った。得られた泳動像からアルブミンの純度を 決定した。

\section{3 結果と考察}

\subsection{HSA の定量}

まず白金コロイド染色法による HSA の検出感度を測定した。 HSA 標準物質を精科後, 定容量のリン酸塩緩衝液に溶解し HSA 標準液とした。この標準液を一定量採取し種々の濃度の HSA を 調製した。この HSA 希釈溶液を $10 \mu l \mathrm{CE}$ 膜上に滴下し乾燥固 定後白金コロイド染色法で定量した。その結果 $0.1 \mathrm{pg} / 10 \mu l$ 濃

7) J. Turkevich, G. Kim, Science, 169, 873(1970).

8) K. Aika, L. L. Ban, I. Okrura, S. Namba, J. Turkevich, J. Res. Inst. Catal. Hokkaido Univ., 24, 56(1976).

9）難波征太郎, 大倉一郎, 表面, 21，450(1983).

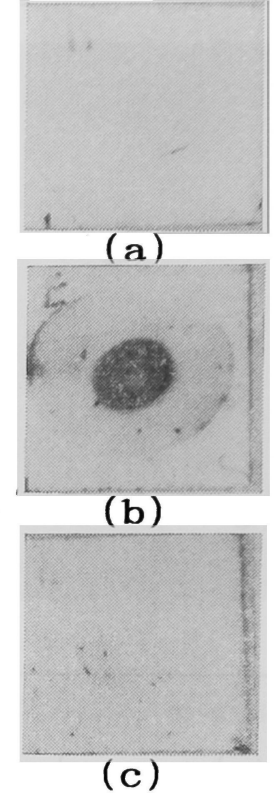

Fig. 1 Detection of HSA by using affinity chromatography and platinum staining method

(a) Eluate (phosphate buffer, pH 7.0) before the introduction of HSA in the column

(b) Eluate (acetic acid buffer, $\mathrm{pH} \mathrm{4.0)}$ after the introduction of HSA in the column

(c) Eluate (phosphate buffer, $\mathrm{pH}$ 7.0) after the procedure (b)

度の HSA まで検出され ELISA 法以上の感度(10)を有することを 確認した。さらに, 同様の HSA 標準液を試料とし, 抗 HSA 抗 体を配位子としたアフィニティークロマトグラフィーにより分 離・回収した HSA を含む溶出液について白金コロイド染色を行 つた。得られた染色結果の一例を図 1 に示す。（a）の染色像は, 実験前のカラムをリン酸塩緩衝液で洗浄した際の洗液を白金コ口 イド染色したものでまったく染色されずタンパク質が存在しな いことがわかる。（b）の染色像は，次に示す方法により得られた ものである。まず HSA 標準液をカラムに注入し室温で 30 分間 放置後, pH 7.0 リン酸塩緩衝液 $50 \mathrm{ml}$ を用いカラムを洗浄し た。さらに $\mathrm{pH} 4.0$ 酢酸塩緩衝液 $3.5 \mathrm{ml}$ をカラムに注入し室温 で 30 分間放置することにより抗体に吸着した HSA の溶出を行 つた。この操作により得られた溶出夜を CE 膜上に滴下し白金コ ロイド染色した。この結果から HSA の溶出された箇所が染色さ れていることがわかる。また，（c）はHSA 溶出後りン酸塩緩衝 液 $50 \mathrm{~m} l$ でカラムを洗浄した後の洗浄液を $\mathrm{CE}$ 膜上に滴下し白金 コロイド染色を行い得られた染色像で, カラムからのタンパフ質 溶出がなくなりカラムが再生されたことがわかる。さらに，染色 像について画像処理装置を用いて測定した染色濃度と HSA 濃度 の対数関係を図 2 に示す。测定した HSA 濃度 $1 \mathrm{ng}$ から $10 \mathrm{ng}$ の範囲において染色濃度と HSA 濃度の対数との間にほぼ直線関 係が得られた。

10）梶沼 宏，医学のあゆみ，113，715(1980). 


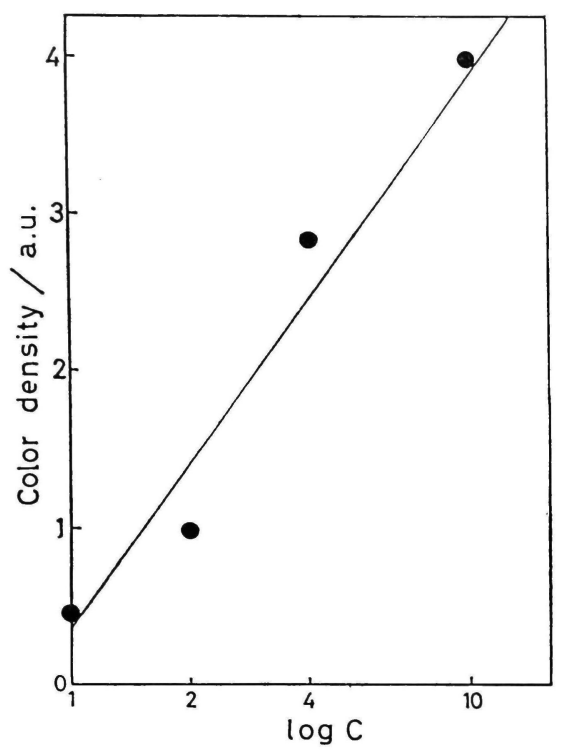

Fig. 2 Relationship between color density vs. $\log C$ $C:$ HSA concentration (ng/10 $\mu l$ )

\section{2 ヒト血清中の HSA の定量}

定量しようとする目的タンパク質が複数のタンパク質と同時に 存在し, かつ微量しか存在しない場合のモデルとして, $10^{5}$ 倍に 希䣋したヒト血清からの HSA の定量について実験を行った。 本実験に使用した健常者血清中のアルブミン濃度は, 4-hydroxy phenylazobenzoic acid 法 ${ }^{11}$ (以下 HABA 法と略記する) で測定 したところ $4.3 \mathrm{~g} / \mathrm{d} l$ であった。したがって, $10^{5}$ 倍に希釈した試 料溶液 $10 \mu l$ には $4.3 \mathrm{ng}$ のアルブミンが含まれることになる。 この試料溶液をアフィニティークロマトグラフィーにかけ, 得ら れた溶出液を白金コロイド染色した染色像を図 3 に示す。（a） は, 試料添加前にカラムをリン酸塩緩衝液で洗浄し得られた洗液 を白金コロイド染色したものである。（b）は希釈血清をカラム 飞添加しリン酸塩緩衝液で洗浄後, カラムに吸着したタンパク質 の解離を行らため酶酸塩緩衝液に置換し室温で 30 分間放置後得 られた液を白金コロイド染色したものである。（c）は酶酸塩緩 衝液でタンパク質を解離後, リン酸塩緩衝液 $50 \mathrm{ml}$ でカラムを洗 浄した後の洗液を白金コロイド染色したものである。図3から希 釈血清をカラムに添加し洗浄後 $\mathrm{pH} 4.0$ の酢酸塩緩衝液で配位子 に用いた抗アルブミン抗体とアルブミンの解離を行った図 $3(\mathrm{~b})$ のみが白金コロイド染色法により染色されていることがわかる。 さらに, この染色像について画像処理装置による染色濃度測定を 行った結果 $10^{5}$ 倍に希釈した血清中のアルブミン濃度は, 4.76 $\mathrm{ng} / 10 \mu l$ となり, HABA 法とよく一致した。本法を用いるとこ のように希薄溶夜中のアルブミンを定量することができる。

抗 HSA 抗体を配位子としたアフィニティークロマトグラフィ 一により, ヒト血清中のアルブミンのみが分離回収されているか どらかを調べる目的で, 回収した溶液を濃縮し二次元電気泳動を 行った。泳動終了後クマジー染色により得られた分析像を図 4 （a）に示す。なお，（b）の泳動像は, 血清試料をそのまま二次 元電気泳動法により分析したものである。図から,アフィニティ

11) D. D. Rutstein, E. F. Ingenito, W. E. Reynols, J. Clin. Inv., 33, 211(1954).

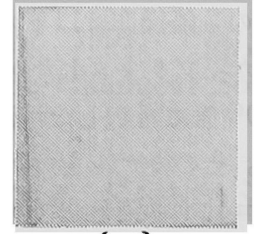

(a)

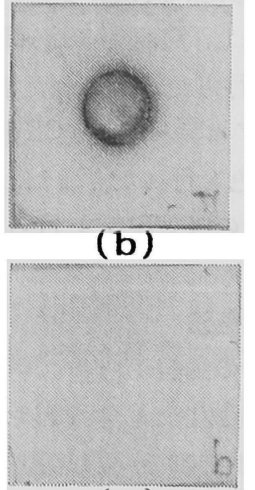

(c)

Fig. 3 Detection of HSA from whole human blood serum by affinity chromatography and platinum staining method

(a) Eluate (phosphate buffer, $\mathrm{pH} 7.0$ ) before the introduction of $\mathrm{HSA}$ in the column

(b) Eluate (acetic acid buffer, $\mathrm{pH} 4.0$ ) after the introduction of HSA in the column

(c) Eluate (phosphate buffer, $\mathrm{pH}$ 7.0) after the procedure (b)

ークロマトグラフィーを行った試料では, 右側の泳動像のアルブ ミンに当たるスポットのみがクマジー色素に染色され, ヒト血清 からアルブミンのみが, 分離されていることが確認された。

\section{3 インスリンの定量}

抗インスリン抗体を配位子とするアフィニティークロマトグラ フィーに, 白金コロイド染色法を組み合わせた, インスリンの定 量を試みた。ヒトインスリンを精科し, 一定量の $\mathrm{pH} 3.0$ 酶酸塩緩 衝液に溶解しインスリン標準液を調製した。濃度域は $1 \sim 20 \mathrm{ng} /$ $10 \mu l$ である。アフィニティークロマトグラフィー-白金コロイド 染色法により得られた染色像をアルブミンの場合と同様, 画像処 理装置により染色濃度を測定した。得られた染色濃度とインスリ ン濃度の対数関係を図 5 亿示す。測定したインスリン濃度 1 20 ng そおいて, その濃度の対数と染色濃度の間で, 良好な直線関 係が得られた。したがって本法は, 健常者血清中のインスリン濃 度 $2 \sim 7 \mathrm{ng} / 10 \mu l$ を測定するのに十分な感度を有することがわか った。

得られたインスリン濃度と染色濃度の関係（図 5 ) を検量線と し, ヒト血清からのインスリンの分離・定量を試みた。実験には 正常者七ト血清を試料とした。この血清については, あらかじめ サンドイッチ法による ELISA (東洋紡績(株)製)によりインス リン濃度の測定を行った。この血清 $3.5 \mathrm{~m} l$ を検量線作成に使用 したアフィニティーカラムに注入し室温で 20 分間反応後, $\mathrm{pH}$ 7.0 リン酸塩緩衙液 $100 \mathrm{ml}$ によりカラムゲルを洗浄した。その 後, $\mathrm{pH} 4.0$ 酩酸塩緩衝液 $3.5 \mathrm{ml}$ でカラムゲルに吸着したインス 

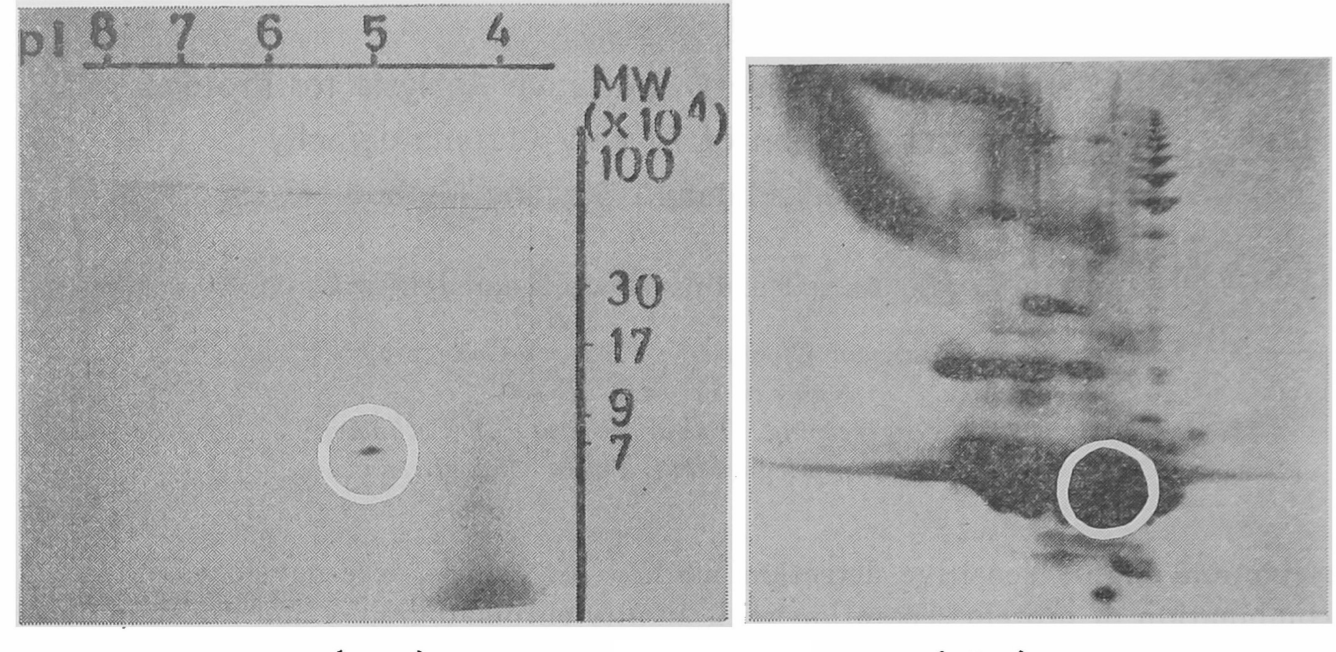

(a)

(b)

Fig. 4 Two-dimensional electrophoresis of HSA eluted from the affinity chromatography (a) and whole human blood serum (b)

HSA is indicated by open circles

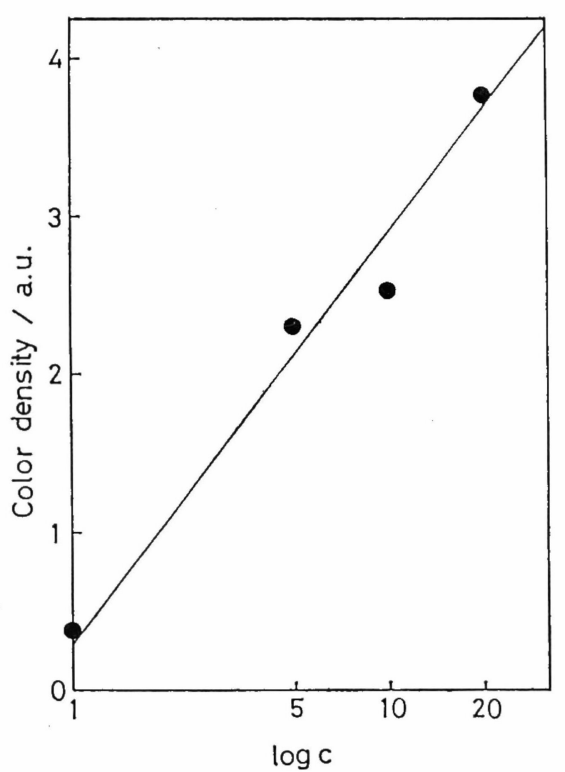

Fig. 5 Relationship between color density vs. $\log C$ $C:$ Insulin concentration (ng/10 $\mu l$ )

リンの溶出を行った。この溶出液について白金コロイド染色扰よ び染色濃度測定を行った。この測定により得られた結果を表 1 に 示す。結果から, サンドイッチ法による ELISA で分析したヒト
Table 1 Relationship between ELISA and Platinum staining method for the determination of human insulin

\begin{tabular}{ccc} 
& $\begin{array}{c}\text { ELISA } \\
(\mathrm{ng} / 10 \mu l)\end{array}$ & $\begin{array}{c}\text { Pt Staining method } \\
(\mathrm{ng} / 10 \mu l)\end{array}$ \\
\hline Sample A & 4.40 & 4.76 \\
Sample B & 5.10 & 5.21 \\
Sample C & 5.30 & 5.28
\end{tabular}

血清中のインスリン濃度と本法によるものとで, 良好な一致がみ られた。このことからヒト血清を試料とした場合でも本法により インスリンの定量が可能なことがわかった。

\section{4 結 論}

以上の笑験結果から,つぎの結論が得られた。

（1）白金コロイド染色法の前段にアフィニティークロマトグ ラフィーを行らことにより, 複数のタンパク質が混在するヒト血 清中から,アルブミンのみを分離定量できることがわかった。そ の感度は, $1 \mathrm{ng}$ であった。

（2）本法を用いインスリンの分離定量を試みたところ，1〜 $20 \mathrm{ng}$ の範囲でインスリン濃度の対数と染色濃度の間に直線とな る関係が得られた。血清中のインスリン濃度測定に十分な感度を 有していることがわかった。 


\section{Specific and Highly Sensitive Quantitative Analysis for Proteins \\ by the Combination of Affinity Chromatography and Colloidal Platinum Staining Method}

Fumihiko Hasumi*, Haruhisa $\mathrm{H}_{\mathrm{ANDA}}$ and Ichiro OKURA**

Department of Industrial Chemistry, Numazu College of Technology; Numazu-shi 410 Japan

** Depertment of Bioengineering, Tokyo Institute of Technology;

Ookayama, Meguro-ku, Tokyo 152 Japan

A specific and highly sensitive detection method for protein was developed. The method is the combination of protein separation with affinity chromatography and the staining method by colloidal platinum. By using this method human serum albumin and human insulin were detected with high sensitivity such as $1 \mathrm{ng}$. 